\title{
A GIS-based methodology toward refining the concept of rural food deserts: A case study from Rutland County, Vermont
}

\author{
John Van Hoesen, ${ }^{a} *$ Brandy Bunkley, ${ }^{a}$ and Cody Currier $^{a}$ \\ Green Mountain College
}

\begin{abstract}
Submitted August 28, 2011 / Revised December 2, 2011; June 8, August 20, October 12, and October 19, 2012 / Accepted October 23, 2012 / Published online March 8, 2013

Citation: Van Hoesen, J., Bunkley, B., \& Currier, C. (2013). A GIS-based methodology toward refining the concept of rural food deserts: A case study from Rutland County, Vermont. Journal of Agriculture, Food Systems, and Community Development. Advance online publication. http://dx.doi.org/10.5304/jafscd.2013.032.006
\end{abstract}

Copyright (C) 2013 by New Leaf Associates, Inc.

\begin{abstract}
There is generally consensus regarding the methodology used to identify and visualize food deserts in urban centers, and to a lesser extent those in rural communities. The primary factor in food desert mapping, however, is distance to food provider without regard for the nutritional value of the food itself. The purpose of this paper is to offer a broader approach toward refining the food desert concept by incorporating a qualitative ranking of food providers based on the likelihood that they offer healthier food options. We apply this technique to Rutland County in rural Vermont by incorporating traditional grocery stores, supermarkets, big-box stores, ${ }^{1}$ general stores, and
\end{abstract}

\footnotetext{
1 "A large retail store whose physical layout resembles a large square or box when seen from above. A big-box store is characterized by a large amount of floor space (generally more than 50,000 square feet [4,645 square meters]), a wide array of items available for sale, and its location in suburban areas....Also called supercenter, superstore, megacenter" (http://www.businessdictionary.com/definition/big-boxstore.html).
}

gas stations, and also including smaller food providers such as farmers' markets, co-ops, farm stands, and community supported agriculture operations. This approach could shift the methodology of identifying food deserts away from just using driving time and distance traveled to food providers meeting a minimum square footage. We propose a methodology that calculates distance to different types of food providers that also evaluates whether consumers have access to healthier food options.

\section{Keywords}

food access, food deserts, GIS, locavore, rural, Vermont

\footnotetext{
a Department of Environmental Studies, Green Mountain College; One Brennan Circle; Poultney, Vermont 05764 USA.

* Corresponding author: John Van Hoesen, Department of Environmental Studies, Green Mountain College; One Brennan Circle; Poultney, Vermont 05764 USA; +1-802-2878387; vanhoesenj@greenmtn.edu
} 


\section{Introduction}

\section{Background}

Many public health researchers and municipal agencies are concerned about rising obesity rates and diet-related health problems and thus are interested in quantifying the spatial relationships between socioeconomic patterns, the consolidation of food providers, and outlets for healthy food. The transition from more widely distributed food providers to centralized providers was accelerated by the trend toward monopsony and vertical integration of the food production and distribution system (Bitto, Morton, Oakland, \& Sand, 2003; Blanchard \& Lyson, 2006; Kaufman, 1999; Lyson \& Raymer, 2000; Schugren-Meyer, 2010). This redistribution of food providers in rural communities limits access to healthy food for low-income families and individuals who lack transportation (Bitto et al. 2003; Glasgow, 2000). One method for better characterizing the transition from local to centralized food distribution is the use of a geographic information system (GIS) to identify potential food deserts within individual census tracts or towns.

Over the last few decades, this transition has resulted in a growing body of literature focused on identifying food deserts. Overall this literature indicates that food deserts indeed exist in the United States, in both urban and rural communities. Other studies highlight issues with large-scale approaches to identifying food deserts using limited data and others focus on trying to assess causality or why food deserts even exist. Differentiating between economic, social, and/or geographic constraints is very complex and difficult to capture within largescale national analyses. These unanswered questions and complex interactions make it difficult to make definitive claims about the existence of food deserts in the United States, the reasons they exist, or measures that may be effective in eliminating them. Narrowing our focus from the national-level approach to local communities may provide more useful data about how to identify and address food deserts, specifically those suspected to exist in rural regions of the United States.

The original food desert concept focused on communities in urban settings with limited access to food as a result of physical or economic barriers (Apparicio, Cloutier, \& Shearmur, 2007; Cummins \& Macintyre, 2002; Ghirardelli, Quinn, \& Foerster, 2010; Larsen and Gilliland, 2008; Pearce, Witten, \& Bartie, 2006; Smoyer-Tomic, Spence, \& Amrhein, 2006; Whelan, Wrigley, Warm \& Cannings, 2002; Wrigley, Warm, \& Margetts, 2003; Wrigley, Warm, Margetts \& Whelan, 2002). Numerous studies argue that residents in an urban setting who have to walk more than 500 meters, equating to a five to seven minute walk, live in a food desert (Guy \& David, 2004;; Smith, Cummins, Taylor, Dawson, Marshall, Sparks, \& Anderson, 2010; Whelen et al., 2002; Wrigley et al., 2002). Fewer studies have explored the spatial relationships between food quality, racial and socioeconomic demographics, and types of food providers within urban communities (Baker, Schootman, Barnidge, \& Kelly, 2006; Glanz, Sallis, Saelens, \& Frank, 2007; Hendrickson, Smith, \& Eikenberry, 2006; Horowitz, Colson, Hebert, \& Lancaster, 2004; Zenk, Schultz, Israel, James, Bao, \& Wilson, 2006). Limited research has focused on identifying food deserts in rural areas where residents often have to travel a substantial distance to purchase food (Furey, Strugnell, \& Mcllveen, 2001; Kaufman, 1999; McEntee \& Agyeman, 2010; Morton \& Blanchard, 2007; Skerratt, 1999; Ver Ploeg et al., 2009). To address the variability associated with rural travel networks, Blanchard and Lyson (2006), McEntee and Agyeman (2010), and Morton and Blanchard (2007) used a travel distance (rather than time) of greater than 10 miles $(16 \mathrm{~km})$ to quantify food deserts in rural communities (U.S. Department of Transportation, n.d.).

Most GIS-based approaches identify food deserts by calculating distance to a food provider based on square footage of the store, assuming that larger stores offer a greater variety of food than smaller stores. While this is true in many communities, this paper explores the assumption that access to a large food provider within a specified distance assures access to healthier food options. There are numerous studies suggesting that access to food providers that offer healthier purchasing options increases the nutritional intake and overall health of the local community (Cheadle, Psaty, Curry, Wagner, Diehr, Koepsell, \& Kristal, 1991; 
Glanz \& Yaroch, 2004; Laraia, Siega-Riz, Kaufman, \& Jones, 2004; Powell, Auld, Chaloupka, O’Malley, \& Johnston, 2007). In a recent report addressing the Vermont Attorney General's Healthy Weight Initiative, the Vermont Retail Environment Working Group (REWG) stated that "central to the effort to address obesity is Vermont consumers' ready access to healthy foods, including fresh fruits and vegetables" (REWG, 2010, p. 1). Glanz et al. (2007) found that "more healthful options were available in grocery than convenience stores" ( $p$. 282) in the Atlanta metropolitan area, and Zenk et al. (2007) found the quality of fresh produce at food stores was significantly lower in mom-andpop and convenience stores. While we recognize the complexities of using the word "healthy" with respect to food as an overall descriptor, we chose to qualitatively assess the quality of food available at various food providers based on our assumptions about greater access to fresh fruits, vegetables, and whole grains, in contrast to providers with more processed foods higher in saturated fats and sugar content (Baker et al., 2006; Glanz et al., 2007; Glanz \& Yaroch, 2004; Hendrickson et al., 2006; Horowitz et al., 2004; Rose, Serrano, Hosig, Haas, Reaves, \& Nickols-Richardson, 2008; U.S. Department of Health and Human Services [USDHHS] \& U.S. Department of Agriculture [USDA], 2005; Walker, Keane, \& Burke, 2010; Zenk et al., 2006).

Another indicator of quality with respect to food purchased from local providers versus food obtained from grocery stores and convenience stores is that the trend toward monopsony has also fueled an interest in fruits and vegetables that provide the highest yield, growth rate, and ability to survive long-distance transport. This trend places a premium on production, while farmers producing for smaller and local venues are more likely to prioritize taste and nutritional quality (Halweil, 2007). Farmers who practice cover-cropping and utilize organic fertilizers, which release nutrients over a longer time period and more slowly than industrial fertilizers, are likely to see higher nutrient uptake by plants (Halweil, 2007). In a similar vein, local foods travel shorter distances and may retain more nutrients; however, we recognize this is still an unresolved claim (Lea, 2005). The way that fruits and vegetables are handled and stored after harvesting also affects nutritional content and quality. Some have also argued that industrial harvesting techniques may be more damaging and result in lower nutrient yields than those practices employed by smaller production facilities (Dobrzański, Rabcewicz, \& Rybczyński, 2006; Dumas, Dadomo, Di Lucca, \& Grolier, 2003; Jeffrey, Brown, Kurilich, Keck, Matusheski, Klein, \& Juvik, 2003; Lee \& Kader, 2000). This background is intended to provide further context for creating an ordinal ranking system that ascribes the highest ranking to supermarkets and local food providers, a moderate ranking to general and grocery stores, and the lowest ranking to convenience stores and gas stations, based on their diversity in healthier food options. We also rank each provider based on assumptions about potential access to healthier food options (as defined above).

McEntee and Agyeman (2010), who provide the highest resolution analysis of food deserts in Vermont, note the absence of farm stands, community supported agriculture (CSA) operations, farmers' markets, and other small food providers in their analysis. In response, we present one possible methodology for identifying rural food deserts by incorporating smaller local food providers that are often excluded from analyses because they do not meet a minimum square footage.

\section{Study Location}

Rutland County is located in southwestern Vermont, south of Addison County and north of Bennington County, and borders the eastern edge of New York state (figure 1). It encompasses an area of 945 square miles (approximately 2,450 $\mathrm{km}^{2}$ ) and contains 28 towns with a total population of 63,000 residing in approximately 32,000 households. The median household income is about USD 37,000, with about 10 percent of the population living below the poverty level (U.S. Census Bureau, 2009). The county also suffers from a 24 percent obesity rate, one of the highest rates in the state (County Health Rankings, n.d.).

In contrast, the county also contains a strong locally based food network comprising farms, farmers' markets, co-ops, and CSAs. These providers offer a variety of foods, including fruits, vegetables, grains, meat products, baked goods, 
honey, and maple products. Some offer a combination of these food products and others focus on a single product. Seasonality of products and duration of the season vary depending on the product, farm location, and scale of the operation. Supply and demand for these local products has risen over the last five years (table 1 ) according to the Rutland Area Farm and Food Link (RAFFL).

We selected this county for an initial case study because: (1) it is considered completely rural based on the USDA RuralUrban Continuum Code classification scheme, (2) it has diverse socioeconomic characteristics, and (3) information about local and smaller food providers was readily accessible from RAFFL (U.S. Census Bureau, 2009; RAFFL, 2010; USDA, 2004).

\section{Methodology}

We utilize a similar analysis as many previous workers by using a GIS to quantify the distance between residential buildings and food providers (Donkin, Dowler, Stevenson, \& Turner, 2000; Larsen \& Gilliland, 2008; McEntee \& Agyeman, 2010; Pearce et al., 2006). However, we additionally

\section{Figure 1. Location of Study Area Indicating the Location of Food Providers Within Each Town of Rutland County, Vermont}

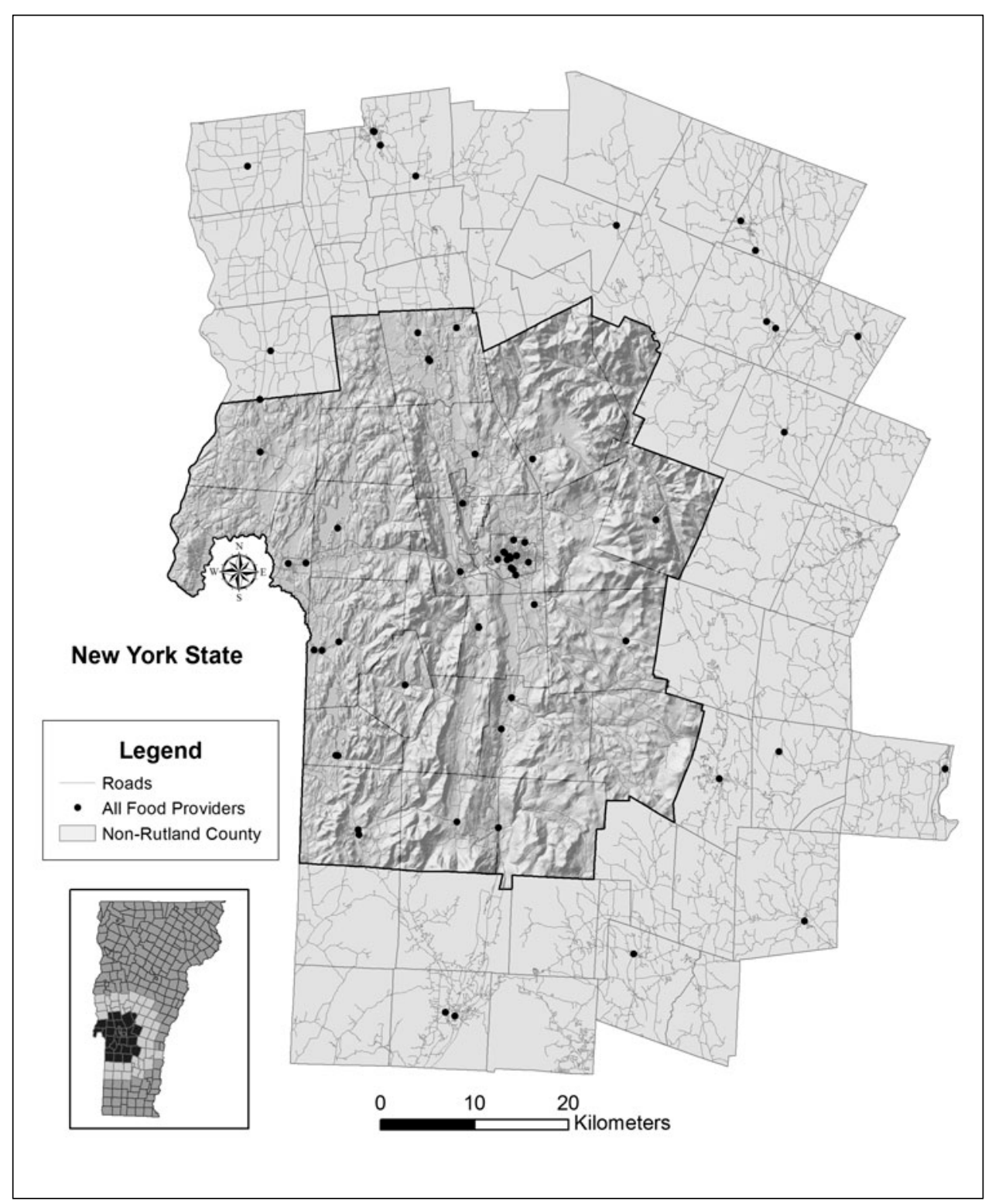

include smaller convenience stores, farmers' markets, farm stands, and co-ops, and rank all food providers using an ordinal scale ranging from 1 to 3 (table 1). A ranking of 1 in the diversity column indicates a lower variety of food offerings at gas stations and convenience stores and 3 indicates the highest variety of food products at supermarkets (Glanz et al., 2007; Hendrickson et al., 2006). A ranking of 1 in the processed column indicates a higher prevalence of access to more processed and 


\section{Table 1. Summary of the Increase in Local Food Providers in Rutland County}

\begin{tabular}{lccc}
\hline Fear & $\begin{array}{c}\text { Farms and } \\
\text { Farm Stands }\end{array}$ & $\begin{array}{c}\text { Farmers' } \\
\text { Markets }\end{array}$ & $\begin{array}{c}\text { Community } \\
\text { Supported } \\
\text { Agriculture } \\
\text { Operations (CSAs) }\end{array}$ \\
\hline 2006 & 23 & 5 & 6 \\
\hline 2007 & 53 & 7 & 8 \\
\hline 2008 & 62 & 7 & 9 \\
\hline 2009 & 62 & 8 & 12 \\
\hline 2010 & 88 & 9 & 16 \\
\hline
\end{tabular}

Based on information extracted from the RAFFL Locally Grown Guide (2006-2010). food supplies, but are not primarily focused on purchasing local fruits, vegetables, and whole grains. Gas stations and small convenience stores typically offer the least healthy and lowest diversity of all providers (Blanchard \& Lyson, 2006; Glanz et al., 2007; Kaufman, 1999). This ranking system allowed us to better characterize the likelihood of access to healthier food options, while also taking into account the lower diversity in food options offered by many smaller providers.

Larger food providers were

extracted from the national directory of

Table 2. Summary of Ranking Values Used To Reclassify Food Sources in Rutland County

\begin{tabular}{lrcc}
\hline Type & $\#$ & $\begin{array}{c}\text { Diversity } \\
\text { Rank }\end{array}$ & $\begin{array}{c}\text { Processing } \\
\text { Rank }\end{array}$ \\
\hline Grocery Store & 16 & 2 & 2 \\
Supermarket & 7 & 3 & 3 \\
Big-box Store & 1 & 2 & 2 \\
General Store & 18 & 2 & 2 \\
Gas Station & 27 & 1 & 1 \\
Farmers' market & 7 & 2 & 3 \\
Co-op & 2 & 2 & 3 \\
Farm Stand & 17 & 2 & 3 \\
CSA & 2 & 2 & 3 \\
\hline
\end{tabular}

Note: A ranking of 1 suggests access to lower diversity and more processed food options while a ranking of 3 suggests greater diversity of less processed food options. These rankings are based on our assumptions that farmers' markets, co-ops, CSAs and farm stands provide a greater percentage of fresh and local food products, while recognizing that supermarkets and some grocery stores receive fruits and vegetables from regional food distributors year-round.

less healthful options, while a ranking of 3 indicates a higher likelihood of more healthful and less processed food (USDHS, 2005; Zenk et al., 2006). We posit that farmers' markets, co-ops, CSAs, and farm stands primarily offer fresh, locally grown, healthy food options, but recognize there are seasonal fluctuations in the quantity and variety of food they can provide (Ghirardelli et al., 2010; Morland, Diez Roux, \& Wing, 2006; Liefert \& Niggli, 2009; Short, Guthman, \& Raskin, 2007; Worthington, 2001). Supermarkets, big-box stores, and grocery stores experience less interruption in authorized Supplemental Nutrition Assistance Program (SNAP) foodstores (USDA, n.d.) following Hosler and Dharssi (2010) and Ver Ploeg et al. (2009). The locations of smaller food providers were plotted by parsing addresses listed in RAFFL's Locally Grown Guide through BatchGeo, an online geocoding service (BatchGeo LLC, n.d.). The locations of residential homes were extracted from an E911 database obtained from the Vermont Center for Geographic Information (VCGI, n.d.). A 1:5,000 scale vector roads layer was also obtained from VCGI and used to build the travel network necessary for distance analysis.

We used the Closest Facility function of the Network Analyst Extension within ArcGIS 10 to calculate the distance between each residential building and the closest food provider along a high-resolution road network. The resulting Routes were joined to each corresponding residential point (i.e., join table) and then residential units were joined to towns within Rutland County. This spatial join aggregated the residential units and produced columns summarizing both the average and maximum travel distances for each town.

We calculated distance between residential units and food providers under four scenarios based on our ranking of food processing: (1) distance to all food providers, (2) distance to fresh and local food providers (lowest likelihood of selling processed food), (3) distance to supermarkets and grocery stores (moderate likelihood of selling processed food), and (4) distance to convenience stores and gas stations (highest likelihood of selling 
processed food). To ensure we did not overestimate travel distance to supermarkets and grocery stores, we included SNAP data for providers in towns outside Rutland County. We did not have access to high-quality data summarizing locally sourced food for surrounding towns. Our analysis included a total of 99 food providers; 31 were identified with a higher likelihood of selling healthier food options, 41 with a moderate likelihood, and 27 with a lower likelihood of healthy food options (table 2).

Our final analysis involved creating a composite index reflecting the overall access to different food providers. Supermarkets were given a value of 1000, grocery stores and food markets a value of 100 , and local farms, farmers' markets, CSAs, farmstands, and co-ops a value of 10 . We left convenience stores out of this analysis because we were trying to capture the overlap in access to those food providers offering healthier food options. Values associated with each provider were then added together for each town to reflect the overlap in food access. For example, a value of 1450 would indicate the town contains one supermarket, four grocery stores and five smaller local food providers.

\section{Results}

When we calculated distance between all food providers and residential units in Rutland County we did not identify any food deserts (figure 2). The highest average travel distance was 6.91 miles $(11.12 \mathrm{~km})$ and maximum travel distance was 8.41 miles $(13.53 \mathrm{~km})$ (table 3$)$. In towns with greater than 1,000 housing units, the average travel distance was considerably lower; for example the highest average distance was 1.89 miles $(3.04 \mathrm{~km})$ in the town of Clarendon. When we calculated distance using supermarkets, grocery stores, and general stores, we identified three towns that contain residents who travel greater than 10 miles to purchase food (figure 3). This analysis includes food providers for towns that are located within a 10 -mile radius of any Rutland County resident. The average travel distance within the town of Walling-

\section{Figure 2. Maps Illustrating the Average and Maximum Distance to All Food Providers Within Rutland County}

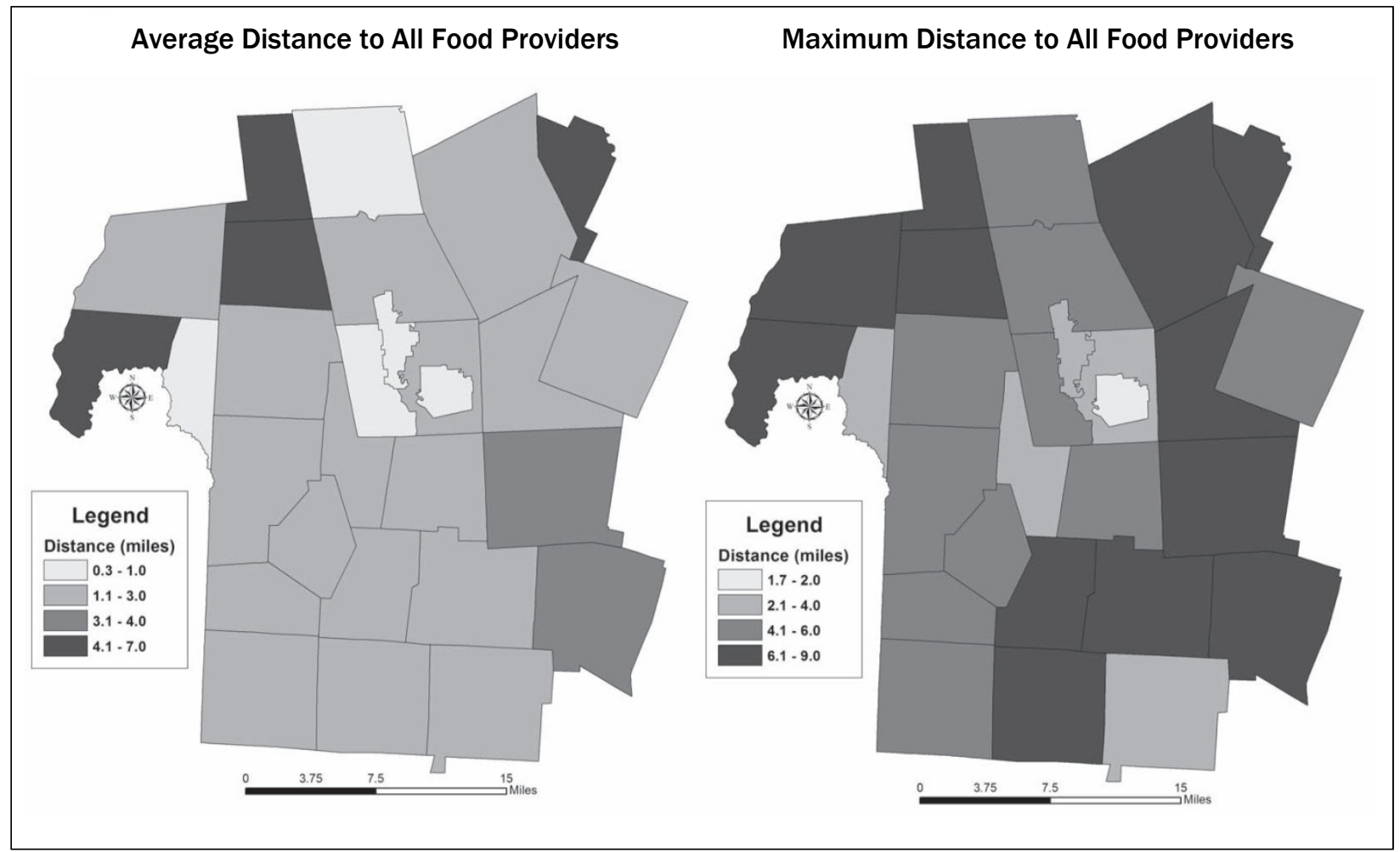


ford was 3.29 miles $(5.29 \mathrm{~km})$ and the maximum travel distance was 13.08 miles $(21.05 \mathrm{~km})$. The average travel distance within the town of $\mathrm{Mt}$. Holly was 8.34 miles $(13.42 \mathrm{~km})$ and the maximum travel distance was 13.03 miles $(20.97 \mathrm{~km})$. The average travel distance within the town of Shrewsbury was 5.76 miles $(9.27 \mathrm{~km})$ and the maximum travel distance was 11.80 miles $(18.99 \mathrm{~km})$. Running this same query with the inclusion of small local food providers decreased the average travel distance from 1.93 miles to 1.57 miles $(3.11 \mathrm{~km}$ to
$2.53 \mathrm{~km}$ ) and the maximum travel distance from 10.80 to 8.41 miles $(17.38 \mathrm{~km}$ to $13.53 \mathrm{~km})$.

When we further narrowed the analysis and calculated distance using the highest-ranked food providers, we identified two towns with residents who travel greater than 10 miles to purchase fresh and local food (figure 4). The average travel distance within the town of Benson was 1.52 miles $(2.45 \mathrm{~km})$ and the maximum travel distance was 12.96 miles $(20.86 \mathrm{~km})$. The average travel distance within the town of Chittenden was 8.05 miles

Table 3. Summary of the Average and Maximum Travel Distance Between Residential Buildings and All Food Providers in Rutland County

\begin{tabular}{|c|c|c|c|c|c|}
\hline Town & \# of Homes & $\begin{array}{c}\text { Average Distance } \\
(\mathrm{Mi})\end{array}$ & $\begin{array}{c}\text { Average Distance } \\
(\mathrm{Km})\end{array}$ & $\begin{array}{c}\text { Maximum } \\
\text { Distance (Mi) }\end{array}$ & $\begin{array}{c}\text { Maximum Distance } \\
(\mathrm{Km})\end{array}$ \\
\hline Benson & 447 & 2.11 & 3.40 & 6.32 & 10.17 \\
\hline Brandon & 1,583 & 0.92 & 1.48 & 4.8 & 7.72 \\
\hline Castleton & 1,637 & 1.35 & 2.17 & 5.8 & 9.33 \\
\hline Chittenden & 578 & 2.37 & 3.81 & 8.41 & 13.53 \\
\hline Clarendon & 1,112 & 1.89 & 3.04 & 4.13 & 6.65 \\
\hline Danby & 658 & 2.26 & 3.64 & 6.26 & 10.07 \\
\hline Fair Haven & 991 & 0.52 & 0.84 & 3.45 & 5.55 \\
\hline Hubbardton & 320 & 4.69 & 7.55 & 8.12 & 13.07 \\
\hline Ira & 178 & 1.57 & 2.53 & 3.75 & 6.04 \\
\hline Killington & 808 & 2.42 & 3.89 & 5.8 & 9.33 \\
\hline Mendon & 462 & 2.15 & 3.46 & 6.09 & 9.80 \\
\hline Middletown Springs & 394 & 1.42 & 2.29 & 4.28 & 6.89 \\
\hline Mount Holly & 823 & 3.46 & 5.57 & 7.96 & 12.81 \\
\hline Mount Tabor & 110 & 1.24 & 2.00 & 3.37 & 5.42 \\
\hline Pawlet & 688 & 1.86 & 2.99 & 4.5 & 7.24 \\
\hline$\underline{\text { Pittsfield }}$ & 59 & 6.91 & 11.12 & 7.83 & 12.60 \\
\hline Pittsford & 1,244 & 1.9 & 3.06 & 5.96 & 9.59 \\
\hline Poultney & 1,301 & 1.41 & 2.27 & 5.98 & 9.62 \\
\hline Proctor & 725 & 0.89 & 1.43 & 2.52 & 4.06 \\
\hline Rutland & 1,571 & 1.35 & 2.17 & 3.62 & 5.83 \\
\hline Rutland City & 5,012 & 0.33 & 0.53 & 1.73 & 2.78 \\
\hline Shrewsbury & 530 & 3.01 & 4.84 & 7.41 & 11.93 \\
\hline Sudbury & 308 & 5.61 & 9.03 & 7.46 & 12.01 \\
\hline Tinmouth & 233 & 2.74 & 4.41 & 6.00 & 9.66 \\
\hline Wallingford & 895 & 1.72 & 2.77 & 8.1 & 13.04 \\
\hline Wells & 645 & 1.7 & 2.74 & 5.24 & 8.43 \\
\hline West Haven & 125 & 4.54 & 7.31 & 8.16 & 13.13 \\
\hline West Rutland & 840 & 0.94 & 1.51 & 5.37 & 8.64 \\
\hline
\end{tabular}


$(12.96 \mathrm{~km})$ and the maximum travel distance was 14.42 miles $(23.21 \mathrm{~km})$. Our final distance analysis used only the lowest-ranked food providers; we identified one town with an average travel distance exceeding 10 miles, and 9 towns with a maximum travel distance greater than 10 miles (figure 5). The maximum travel distance to access food providers for residents within Rutland County is summarized in figure 6.

Figure 7 illustrates the final composite index map created to better visualize access to different types of food providers for each town in Rutland County. Index values are generally higher in the larger population centers that can support a greater diversity of businesses and express a wider variation in food provider types. The towns of Brandon, Fair Haven, Rutland/Rutland City, Poultney, and West Rutland all contain at least one supermarket, between one and nine grocery or general stores, and between one and three smaller local food providers. These five towns contain the highest diversity in food providers and offer the best experience for consumers interested in supplementing traditional supermarket shopping with food obtained from smaller, local food providers.

\section{Discussion}

Using the criteria proposed by Morton and Blanchard (2007), we did not identify any food deserts within Rutland County. This is consistent with a statewide analysis conducted by McEntee and Agyeman (2010). However, our analysis differentiates access to food based on a qualitative assessment of access to healthier food options, uses a high-resolution road network, and includes many smaller food providers. Although there are no towns with a mean travel distance greater than 10 miles $(16 \mathrm{~km})$, we illustrate the impact of including small food providers when calculating the mean travel distance to providers; when local providers were included, the mean travel distance in Rutland County decreased 18.65 percent, and the maximum travel distance decreased 22.13 percent. We believe this is an important finding of the methodology presented in this paper because it suggests that some towns or communities could be incorrectly labeled food deserts if these smaller providers are not taken into consideration.

\section{Figure 3. Map Illustrating the Average Distance to Grocery Stores and General Stores Within Rutland County}

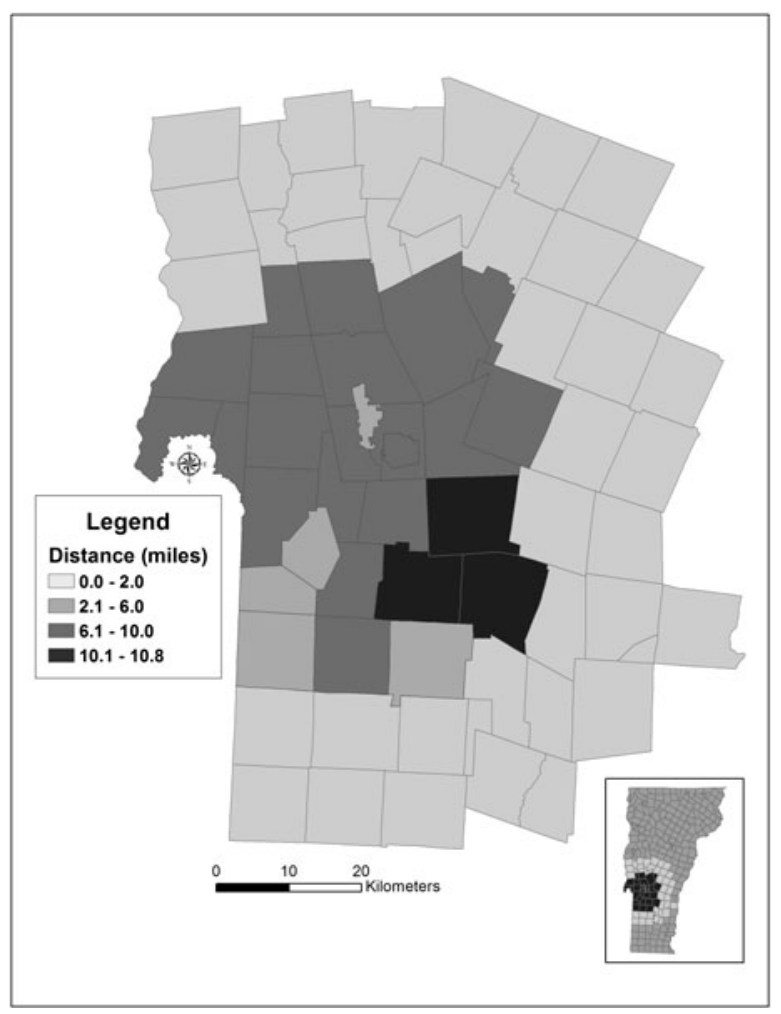

We argue that food desert analyses should incorporate as many local food providers as possible to better characterize access to healthier food options, as described by the USDA. A growing interest in locally grown food and the emerging locavore movement will play an important role in addressing community health issues (such as obesity), food security, and redefining both urban and local food desert criteria (Bailkey \& Nasr, 2000; Broadway, 2010; Khan, Sobush, Keener, Goodman, Lowry, Kakietek, \& Zaro, 2009; Parker, 2010; Timmons, Wang, \& Lass, 2008). Including these smaller food providers decreases the likelihood of identifying a food desert, but we believe it better illustrates the availability of healthier food options. We also recognize the complexities of incorporating food providers that may be seasonal, provide one specific food product, and may be more susceptible to market fluctuations. The greatest challenge is obtaining coordinates to plot the location of many small-scale providers such as small 
Figure 4. Maps Illustrating the Average (A) and Maximum (B) Distance to Food Providers with a Low Likelihood of Selling Processed Food Within Rutland County

A

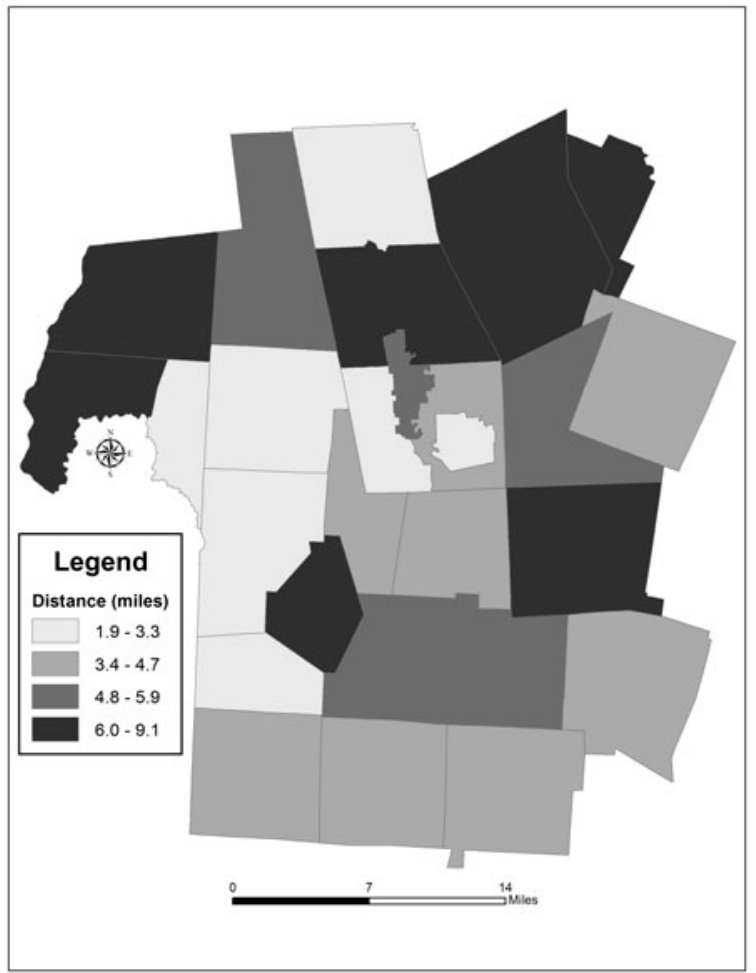

B

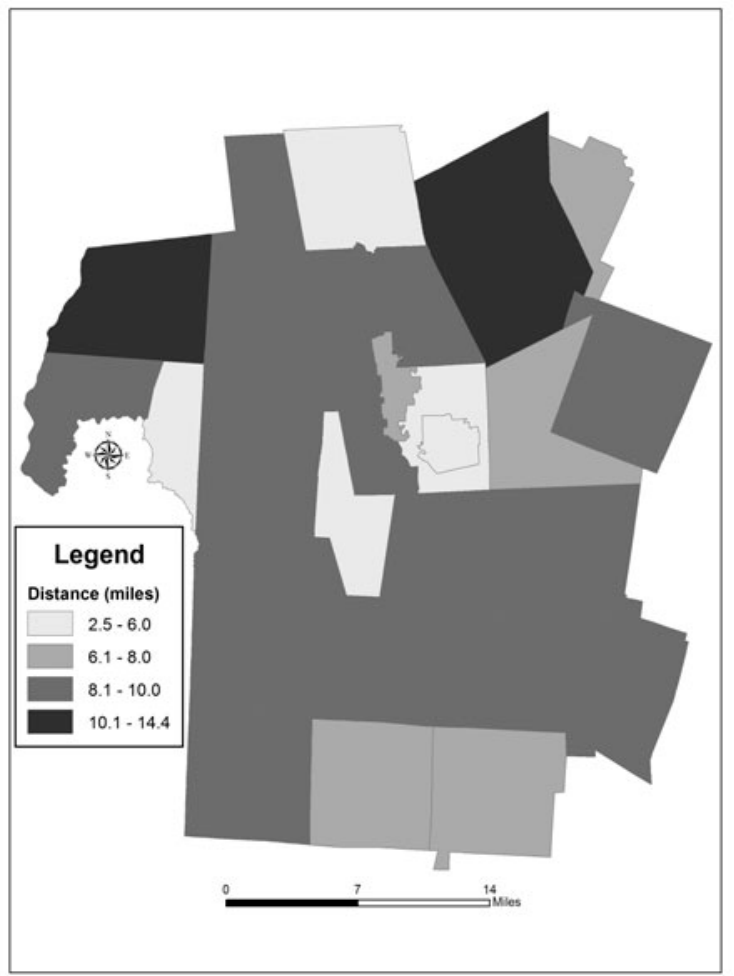

Figure 5. Maps Illustrating the Average (A) and Maximum (B) Distance to Food Providers with a High Likelihood of Selling Processed Food Within Rutland County

A

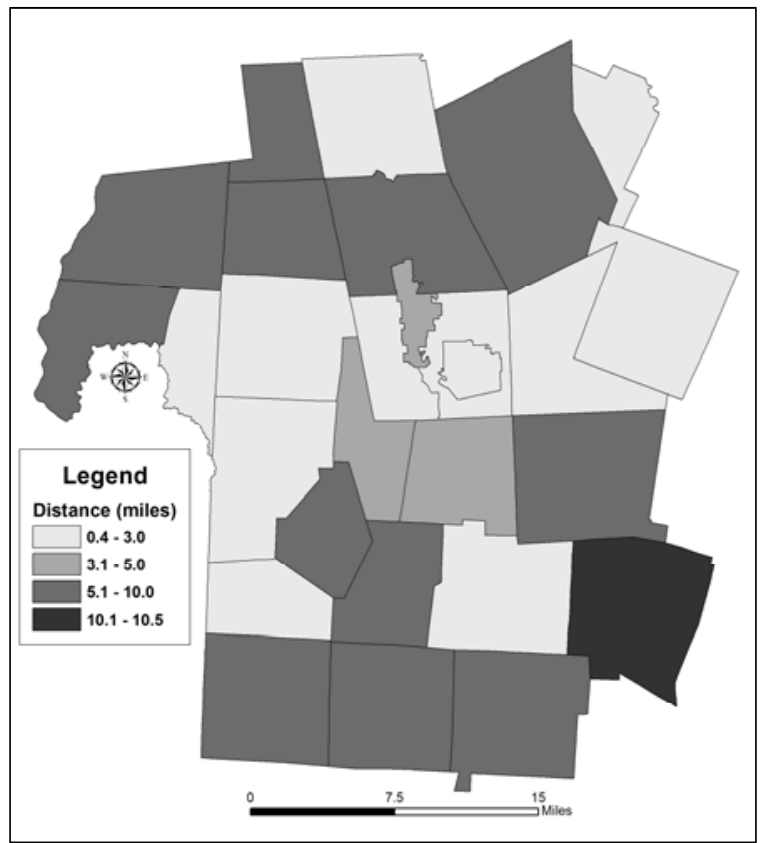

B

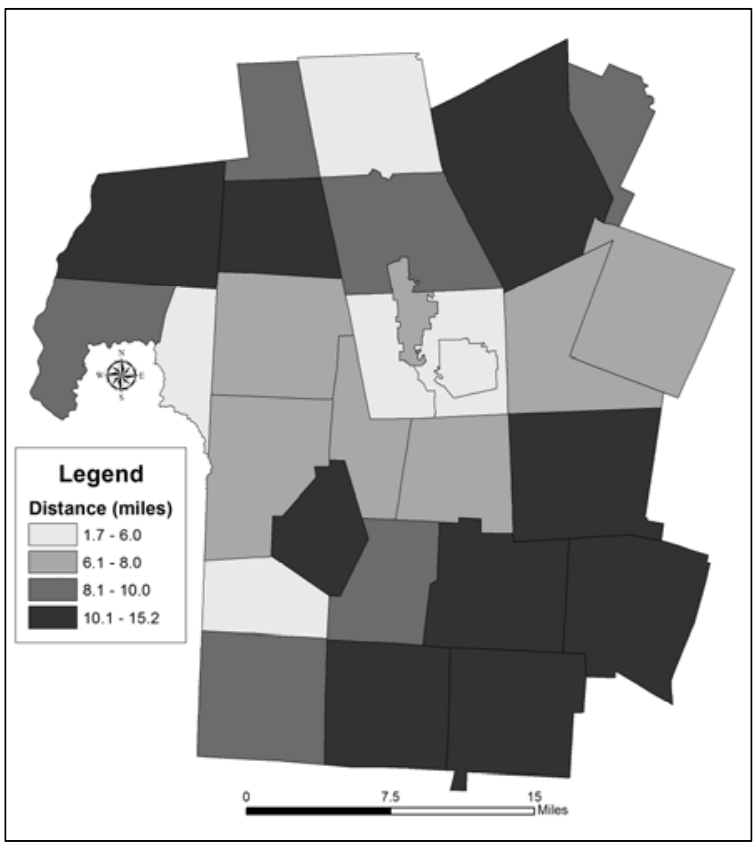


Figure 6. Histograms Summarizing the Distance Traveled from Rutland County Residents to All Food Providers (A) and Providers Differentiated by High (B), Moderate (C) and Low (D) Likelihood of Access to Less Processed Food

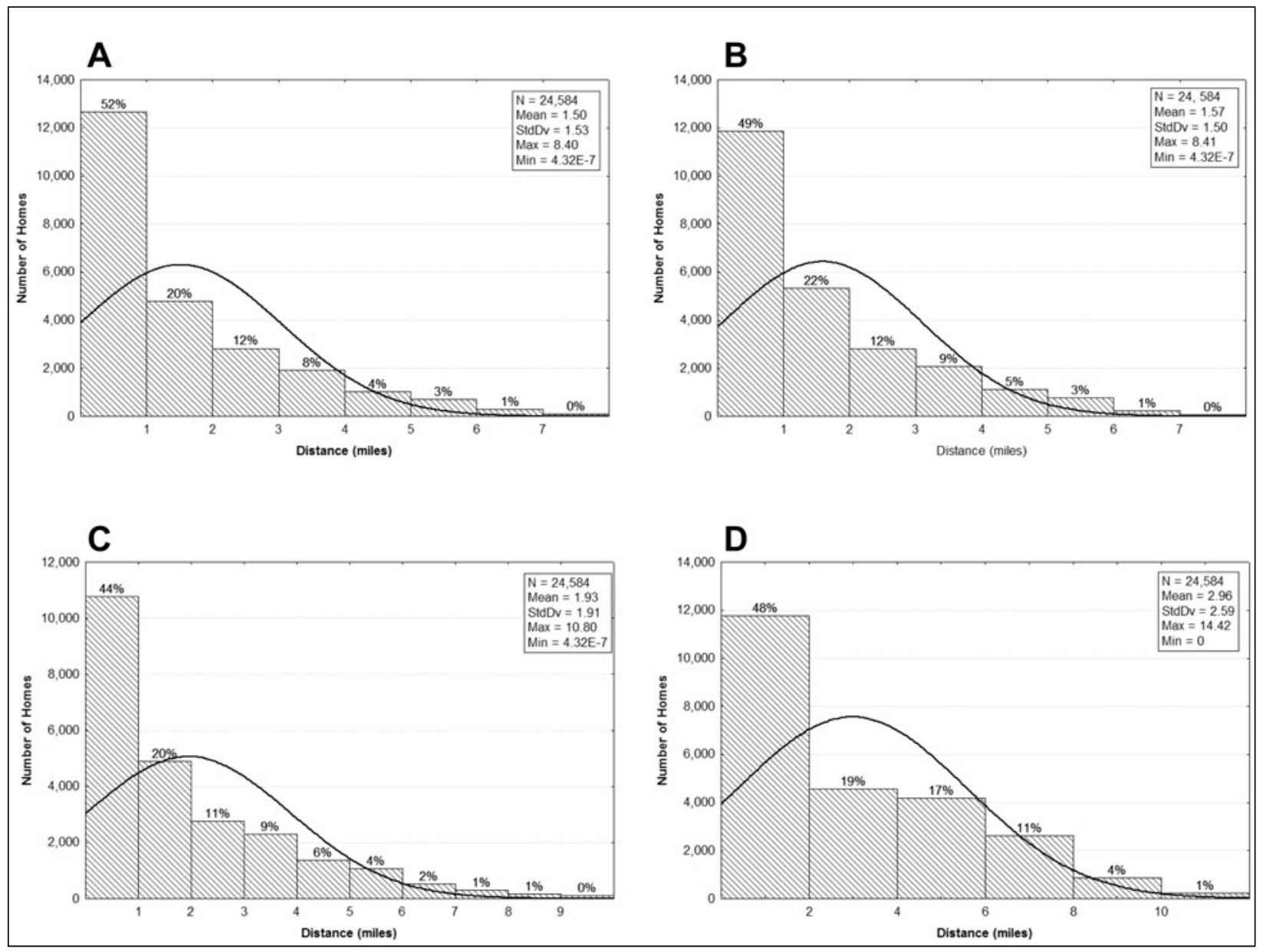

garden stands, food pantries, and the increasing numbers of community gardens (Hendrickson et al., 2006; Morton \& Blanchard, 2007).

\section{Conclusions and Future Work}

McEntee and Agyeman (2010) stated that small local food providers "could play an increasingly important role in how people access food." We offer a new methodology for characterizing rural food deserts that illustrates this is true for Rutland County and argue that when possible, smaller food providers should be included in rural food desert analyses. At the very least this will offer a better characterization of seasonal access to food and the capacity of individual communities to support the growing locavore demand. Additionally, to help support the "Let's Move" campaign, Michelle Obama gathered support from numerous regional and national retailers such as Walmart, Walgreens and SuperValu. These retail chains have committed to open or expand approximately 1,500 stores that will offer fresh fruits, vegetable and food staples in identified food deserts (Mui, 2011). Vermont is also pursuing a Healthy Retailer initiative that promotes access to healthier food options (REWG, 2010). As these programs and initiatives become more widespread, participating retailers should be incorporated into future studies, but will need to be evaluated on a case-by-case basis. For example, Rutland County contains a Walmart that currently 


\section{Figure 7. Composite Index of Food Access in Rutland County Created by Ranking Food Providers by Type and Adding the Total Number of Providers in Each Town}

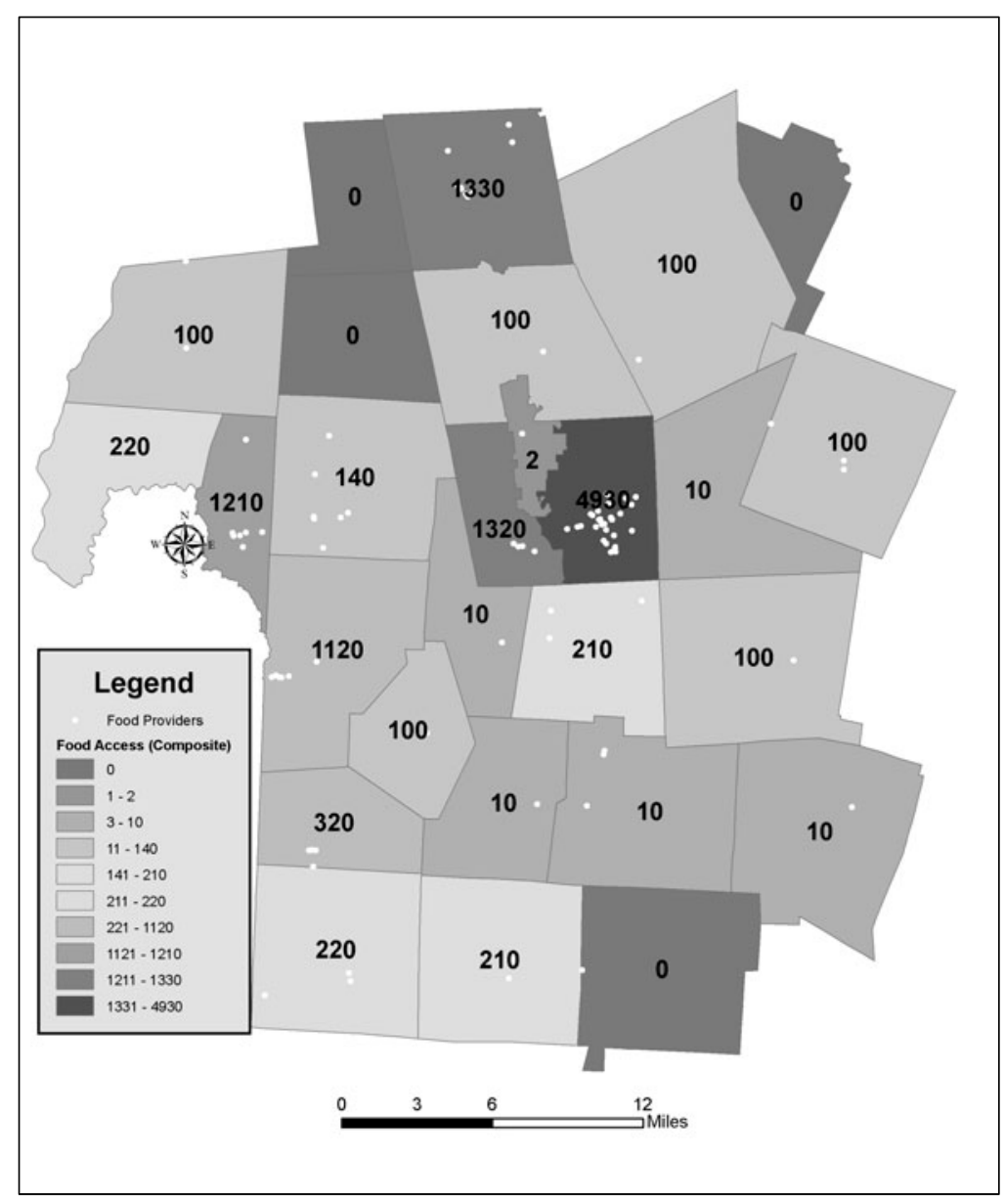

Donley, 1997; Glanz et al., 2007; Kaufmann, 1999; Lewis, Sloane, Nascimento, Diamant, Guinyard, Yancey, \& Flynn, 2005; Powell, Slater, Mirtcheva, Bao, \& Chaloupka, 2007), while others have discovered lower pricing in supermarkets and grocery stores versus smaller convenient stores (Chung \& Meyers, 1999; Kaufman, MacDonald, Lutz, \& Smallwood, 1997). So if we are only concerned with distance to a food provider, a resident may not be identified as living in a food desert, but the cost of healthier food options at the closest store could be prohibitive. With increased interest in the "Let's Move" campaign and the "Healthy Corner Store Initiative" from smaller food providers, some communities may see increased access to healthier options with lower pricing.

However, it is also important to clarify that financial access is not the only variable that influences healthier food choices; other studies have identified issues of motivation and frequently a lack of nutritional awareness - or informational access (Dibsdall, Lambert, Bobbin, \& Frewer, 2003; Lawrence et al., 2007; McEntee, 2008). does not sell fresh fruits or vegetables. This caseby-case evaluation in other rural communities will change the assumptions we made in this paper since we currently assume these food providers offer little in the way of fresh fruits and vegetables; store rankings would need to be adjusted to reflect local changes in response to the Let's Move campaign.

One aspect we do not address in this methodology is the concept of social exclusion as it relates to the decisions to purchase healthier food based on financial constraints. If residents cannot afford healthier food options, then they could suffer from inadequate financial access (Bossert, D'Ambrosio, \& Peragine, 2007; Hendrickson et al., 2006; McEntee, 2008). Numerous studies have identified examples of financial exclusion (Alwitt \&
Finally, while we understand the attraction of developing one methodology that can be applied uniformly to the entire country (McEntee \& Agyeman, 2010), we believe Morton and Blanchard's (2007) travel-time estimate should be refined to better characterize regional differences in sinuosity of travel networks and topographic barriers. For example, a 10-mile drive in rural Vermont or Colorado will likely result in a longer travel time than a similar10-mile drive in rural Iowa or Florida. Assuming a fixed travel time for the entire United States most likely underestimates the distribution of food deserts. It also assumes that travel time is the limiting factor, rather than incorporating socioeconomic status; for example, it is possible that some residents live within 10 miles of a co-op but do not have the financial means to 
shop there. This multivariate analysis of economic and geographic access requires further work in the context of rural food deserts (Donkin et al., 2000; Hendrickson et al., 2006; Kaufman, 1999; Morton et al., 2005).

\section{Acknowledgements}

We would like to thank the Rutland Area Farm and Food Link for their cooperation with this project and India Burnett-Farmer, Philip Ackerman-Leist, and Shepherd Ogden for their helpful discussions.

\section{References}

Alwitt, L. F., \& Donley,T. D. (1997). Retail stores in poor urban neighborhoods. Journal of Consumer Affairs, 31(1), 139-164. http://dx.doi.org/ 10.1111/j.1745-6606.1997.tb00830.x

Apparicio, P., Cloutier, M.-S., \& Shearmur, R. (2007). The case of Montréal's missing food deserts: Evaluation of accessibility to food supermarkets. International Journal of Health Geographics, 6, 4. http://dx.doi.org/10.1186/1476-072X-6-4

Bailkey, M., \& Nasr, J. (2000). From brownfields to greenfields: Producing food in North American cities. Community Food Security News, Fall 1999/Winter 2000, 6-8. Retrieved from http://www.foodsecurity.org/uploads/Brownfields Article-CFSNewsFallWinter1999.pdf

Baker, E. A., Schootman, M., Barnidge, E., \& Kelly, C. (2006). The role of race and poverty in access to foods that enable individuals to adhere to dietary guidelines. Preventing Chronic Disease, 3(3), A76.

BatchGeo LLC. (n.d.). Home page. Retrieved July 26, 2011, from http://www.batchgeo.com/

Bitto, E. A., Morton, L. W., Oakland, M. J., \& Sand, M. (2003). Grocery store access patterns in rural food deserts. Journal for the Study of Food and Society, 6(2), 35-48. http://dx.doi.org/10.2752/152897903786769616

Blanchard, T. \& Lyson, T. (2006). Access to low cost groceries in nonmetropolitan counties: Large retailers and the creation of food deserts. Paper presented at the Measuring Rural Diversity Conference, Washington, DC. Retrieved from the Southern Rural Development Center website: http://srdc.msstate.edu/trainings/presentations archive/2002/2002 blanchard.pdf
Bossert, W., D’Ambrosio, C., \& Peragine, V. (2007). Deprivation and social exclusion. Economica, 74(296), 777-803. http://dx.doi.org/10.1111/j.14680335.2006.00572.x

Broadway, M. (2010). Growing urban agriculture in North American cities: The example of Milwaukee. Focus on Geography, 52(3-4), 23-30. http://dx.doi.org/10.1111/j.19498535.2009.tb00251.x

Cheadle, A., Psaty, B. M., Curry, S., Wagner, E., Diehr, P., Koepsell, T., \& Kristal, A. (1991). Communitylevel comparisons between the grocery store environment and individual dietary practices. Preventive Medicine, 20(2), 250-261. http://dx.doi.org/10.1016/0091-7435(91)90024-X

Chung, C., \& Myers, S. L. (1999). Do the poor pay more for food? An analysis of grocery store availability and food price disparities. Journal of Consumer Affairs, 33(2), 276-296. http://dx.doi.org/10.1111/j.17456606.1999.tb00071.x

County Health Rankings. (n.d.). 2010 Rankings: United States $>$ Vermont $>$ Rutland $(\mathrm{RU})$. Retrieved March 11, 2011, from http://www.countyhealthrankings.org

Cummins, S., \& Macintyre, S. (2002). "Food deserts"evidence and assumption in health policy making. British Medical Journal, 325, 436-438. http://dx.doi.org/10.1136/bmj.325.7361.436

Dibsdall, L. A., Lambert, N., Bobbin, R. F. \& Frewer, L. J. (2003). Low- income consumers' attitudes and behaviour towards access, availability and motivation to eat fruit and vegetables. Public Health Nutrition, 6(2), 159-168. http://dx.doi.org/10.1079/PHN2002412

Dobrzański, B., Rabcewicz, J., \& Rybczyński, R. (2006). Handling of apple: Transport techniques and efficiency, vibration, damage and bruising, texture, firmness and quality (First Ed.). Lublin, Poland: B. Dobrzański Institute of Agrophysics, Polish Academy of Sciences. Retrieved from http://www.ipan. lublin.pl/uploads/mat coe/mat coe27.pdf

Donkin, A. J. M., Dowler, E. A., Stevenson, S. J., \& Turner, S. A. (2000). Mapping access to food in a deprived area: The development of price and availability indices. Public Health Nutrition, 3(1), 31-38. http://dx.doi.org/10.1017/S1368980000000057 
Dumas, Y., Dadomo, M., Di Lucca, G., \& Grolier, P. (2003). Effects of environmental factors and agricultural techniques on antioxidant content of tomatoes. Journal of the Science of Food and Agriculture, 83(5), 369-382. http://dx.doi.org/10.1002/jsfa.1370

Furey, S., Strugnell, C., \& McIlveen, H. (2001). An investigation of the potential existence of "food deserts" in rural and urban areas of Northern Ireland. Agriculture and Human V alues 18(4), 447-457. http://dx.doi.org/10.1023/A:1015218502547

Ghirardelli, A., Quinn, V., \& Foerster, S. B. (2010). Using geographic information systems and local food store data in California's low-income neighborhoods to inform community initiatives and resources. American Journal of Public Health, 100(11), 2156-2162. http://dx.doi.org/10.2105/AJPH.2010.192757

Glanz, K., Sallis, J. F., Saelens, B. E., \& Frank, L. D. (2007). Nutrition Environmental Measures Survey in Stores (NEMS-S): Development and evaluation. American Journal of Preventative Medicine, 32(4), 282289.

http://dx.doi.org/10.1016/j.amepre.2006.12.019

Glanz, K., \& Yaroch, A. L. (2004). Strategies for increasing fruit and vegetable intake in grocery stores and communities: Pńolicy, pricing, and environmental change. Preventive Medicine, 39(Supplement 2), 75-80. http://dx.doi.org/10.1016/j.ypmed.2004.01.004

Glasgow, N. (2000). Transportation transitions and social integration of nonmetropolitan older persons. In K. Pillemer, P. Moen, E. Wethington, \& N. Glasgow (Eds.), Social Integration in the Second Half of Life (pp. 108-131), Baltimore, Maryland: Johns Hopkins Press.

Guy, C. M., \& David, G. (2004). Measuring physical access to 'healthy foods' in areas of social deprivation: a case study in Cardiff. International Journal of Consumer Studies, 28(3), 222-224.

Halweil, B. (2007, September). Still no free lunch: Nutrient levels in U.S. food supply eroded by pursuit of high yields. Washington, D.C.: The Organic Center. Retrieved from http://organic. insightd.net/reportfiles/Yield Nutrient Density Final.pdf

Volume 3, Issue 2 / Winter 2012-2013
Hendrickson, D., Smith, C., \& Eikenberry, N. (2006). Fruit and vegetable access in four low-income food deserts communities in Minnesota. Agriculture and Human Values, 23(3), 371-383. http://dx.doi.org/10.1007/s10460-006-9002-8

Horowitz, C. R., Colson, K. A., Hebert, P. L., \& Lancaster, K. (2004). Barriers to buying healthy foods for people with diabetes: Evidence of environmental disparities. American Journal of Public Health, 94(9), 1549-1554. http://dx.doi.org/10.2105/AJPH.94.9.1549

Hosler, A. S., \& Dharssi, A. (2010). Identifying retail food stores to evaluate the food environment. American Journal of Preventive Medicine, 39(1), 41-44. http://dx.doi.org/10.1016/j.amepre.2010.03.006

Jeffrey, E. H., Brown, A. F., Kurilich, A. C., Keck, A. S., Matusheski, N., Klein, B. P., \& Juvik, J. A. (2003). Variation in content of bioactive components in broccoli. Journal of Food Composition and Analysis, 16(3), 323-330. http://dx.doi.org/10.1016/S08891575(03)00045-0

Kaufman, P. R. (1999). Rural poor have less access to supermarkets, large grocery stores. Rural Development Perspectives, 13(3), 19-26. Retrieved from http://ers.usda.gov/publications/rdp/rdp1098/ rdp1098c.pdf

Kaufman, P., MacDonald, J., Lutz, S. M., \& Smallwood, D. (1997). Do the poor pay more for food? Item selection and price differences affect low-income household food costs (Agricultural Economic Report No. AER-759). Washington, D.C.: U.S. Department of Agriculture. Retrieved from http://www.ers.usda.gov/ publications/aer-agricultural-economicreport/aer759.aspx

Khan, L. K., Sobush, K., Keener, D., Goodman, K., Lowry, A., Kakietek, J., \& Zaro, S. (2009).

Recommended community strategies and measurements to prevent obesity in the United States. Morbidity and Mortality Weekly Report, 58(RR07), 1-26. Retrieved from http://www.cdc.gov/mmwr/preview/mmwrhtml/ rr5807a1.htm

Laraia, B. A., Siega-Riz, A. M., Kaufman, J. S., \& Jones, S. J. (2004). Proximity of supermarkets is positively associated with diet quality index for pregnancy. Preventive Medicine, 39(5), 869-875. http://dx.doi.org/10.1016/j.ypmed.2004.03.018 
Larsen, K. \& Gilliland, J. (2008). Mapping the evolution of "food deserts" in a Canadian city: Supermarket accessibility in London, Ontario, 1961-2005. International Journal of Health Geographics, 7, 16. http://dx.doi.org/10.1186/1476-072X-7-16

Lawrence, J. M., Devlin, E., Macaskill, S., Kelly, M., Chinouya, M., Raats, M. M., Barton, K. L., Wrieden, W. L., \& Shepherd, R. (2007). Factors that affect the food choices made by girls and young women, from minority ethnic groups, living in the UK. Journal of Human Nutrition \& Dietetics, 20(4), 311319. http://dx.doi.org/10.1111/j.1365277X.2007.00766.x

Lea, E. (2005). Food, health, the environment and consumers' dietary choices. Nutrition \& Dietetics, 62(1), 21-25. http://dx.doi.org/10.1111/j.17470080.2005.tb00005.x

Lee, S. K., \& Kader, A. A. (2000). Preharvest and postharvest factors influencing vitamin $\mathrm{C}$ content of horticultural crops. Postharvest Biology and Technology, 20(3), 207-220. http://dx.doi.org/10.1016/S0925-5214(00)00133-2

Lewis, L. B., Sloane, D. C., Nascimento, L. M., Diamant, A. L., Guinyard, J. J., Yancey, A. K., \& Flynn, G. (2005). African Americans' access to healthy food options in South Los Angeles restaurants. American Journal of Public Health, 95(4), 668-673. http://dx.doi.org/10.2105/AJPH.2004.050260

Liefert, C., \& Niggli, U. (2009). QLIF Integrated Research Project: Advancing organic and low-input food. Retrieved March, 2011 from http://www. qlif.org/Library/leaflets/folder 0 small.pdf

Lyson, T. A. \& Raymer, A. L. (2000). Stalking the wily multinational: Power and control in the US food system. Agriculture and Human Values, 17(2), 199208. http://dx.doi.org/10.1023/A:1007613219447

McEntee, J. (2008). Food deserts: Contexts and critiques of contemporary food access assessments (Working Paper Series No. 46). Cardiff, UK: Centre For Business Relationships, Accountability, Sustainability and Society (Brass Centre). Retrieved from http://www.brass.cf.ac.uk/uploads/WP46Full.pdf

McEntee, J., \& Agyeman, J. (2010). Towards the development of a GIS method for identifying rural food deserts: Geographic access in Vermont, USA. Applied Geography, 30(1), 165-176.

http://dx.doi.org/10.1016/j.apgeog.2009.05.004
Morland, K., Diez Roux, A. V., \& Wing, S. (2006). Supermarkets, other food stores, and obesity: The Atherosclerosis Risk in Communities study. American Journal of Preventive Medicine, 30(4), 333-339. http://dx.doi.org/10.1016/j.amepre.2005.11.003

Morton, L. W., Bitto, E. A., Oakland, M. J., \& Sand, M. (2005). Solving the problems of Iowa food deserts: Food insecurity and civic structure. Rural Sociology, 70(1), 94-112.

Morton, L. W., \& Blanchard, T. C. (2007). Starved for access: Life in rural America's food deserts. Rural Realities, 1(4), 1-10. Retrieved from the Rural Sociological Society website: http://www.ruralsociology.org

Mui, Y. Q. (2011, July 20). First lady, grocers vow to build stores in "food deserts." Washington Post. Retrieved from http://www.washingtonpost. com/business/economy/first-lady-grocers-vow-tobuild-stores-in-food-deserts/2011/07/20/ gIQA9LHRQI story.html

Parker, J. (2010). The case for urban agriculture: Regenerative, buman-scale food production systems in urban landscapes (Unpublished master's thesis). Washington State University, Pullman, Washington.

Pearce, J., Witten, K., \& Bartie, P. (2006). Neighbourhoods and health: A GIS approach to measuring community resource accessibility. Journal of Epidemiology \& Community Health, 60(5), 389-395. http://dx.doi.org/10.1136/jech.2005.043281

Powell, L. M., Auld, M. C., Chaloupka, F. J., O’Malley, P. M., \& Johnston, L. D. (2007). Associations between access to food stores and adolescent body mass index. American Journal of Preventive Medicine, 33(4), S301-S307. http://dx.doi.org/10.1016/j.amepre.2007.07.007

Powell, L. M., Slater, S., Mirtcheva, D., Bao, Y., \& Chaloupka, F. J. (2007). Food store availability and neighborhood characteristics in the United States. Preventive Medicine, 44(3), 189-195. http://dx.doi.org/10.1016/j.ypmed.2006.08.008

Retail Environment Working Group [REWG]. (2010). Report of the Retail Environment Working Group to Attorney General William H. Sorrell. Retrieved from http://www.atg.state.vt.us/assets/files/Report $\% 20$ of $\% 20$ the $\% 20$ Retail $\% 20$ Environment $\% 20$ Working \%20Group.pdf 
Rose, N., Serrano, E., Hosig, K., Haas, C., Reaves, D., \& Nickols-Richardson, S.M. (2008). The 100-Mile Diet: A community approach to promote sustainable food systems impacts dietary quality. Journal of Hunger \& Environmental Nutrition, 3(2-3), 270-285. http://dx.doi.org/10.1080/19320240802244082

Rutland Area Farm and Food Link [RAFFL]. (2010). Annual reports, various years. http://www.rutlandfarmandfood.org/media/

Schugren-Meyer, K. (2010). Agroecology: Integrating a socioecological model into the mainstream agrifood system in the United States (Master's thesis). Lund University, Lund, Sweden. Retrieved from the Lund University LUMES site: http://www.lumes.lu.se/html/lumes theses.aspx

Shaw, H. J. (2006). Food deserts: Towards the development of a classification. Geografiska Annaler: Series B, Human Geography, 88(2), 231-247. http://dx.doi.org/10.1111/j.0435-3684.2006. $\underline{00217 . x}$

Short, A., Guthman, J., \& Raskin, S. (2007). Food deserts, oases, or mirages? Small markets and community food security in the San Francisco Bay area. Journal of Planning Education and Research, 26(3), 352-364. http://dx.doi.org/10.1177/0739456X06297795

Skerratt, S. (1999). Food availability and choice in rural Scotland: The impact of "place." British Food Journal, 101(7), 537-544. http://dx.doi.org/10.1108/00070709910279009

Smith, D. M., Cummins, S., Taylor, M., Dawson, J., Marshall, D., Sparks, L., \& Anderson, A. S. (2010). Neighbourhood food environment and area deprivation: Spatial accessibility to grocery stores selling fresh fruit and vegetables in urban and rural settings. International Journal of Epidemiology, 39(1), 277-284. http://dx.doi.org/10.1093/ije/dyp221

Smoyer-Tomic, K. E., Spence, J. C., \& Amrhein, C. (2006). Food deserts in the prairies? Supermarket accessibility and neighborhood need in Edmonton, Canada. The Professional Geographer, 58(3), 307-326. http://dx.doi.org/10.1111/j.1467-9272.2006. 00570.x

Timmons, D., Wang, Q., \& Lass, D. (2008). Local foods: Estimating capacity. Journal of Extension, 46(5), 5FEA7. Retrieved from http://www.joe.org/joe/2008october/a7.php
U.S. Census Bureau. (2009). 2005-2009 American Community Survey: Population and Housing Narrative Profile, Table NP01. Retrieved March 9, 2011, from http:/ / factfinder2.census.gov/

USDA. (n.d.). SNAP Retail Locator. Retrieved March 14, 2011, from http://www.snapretailerlocator.com/

U.S. Department of Agriculture [USDA]. (2004). United States county typology codes. Retrieved 9 March 2011 from http://www.ers.usda.gov/

U.S. Department of Health and Human Services [USDHHS] and USDA. (2005). Dietary guidelines for Americans 2005. Washington, D.C.: U.S. Government Printing Office. Retrieved from http://www.health.gov/dietaryguidelines/ dga2005/document/pdf/DGA2005.pdf

U.S. Department of Transportation. (n.d.). 2009 National Highway Transportation Survey: 2009 NHTS Trip Chaining Dataset. Retrieved March 11, 2011, from http://nhts.ornl.gov/introduction.shtml

Ver Ploeg, M., Breneman, V., Farrigan, T., Hamrick, K., Hopkins, D., Kaufman, P., Lin, B.-H., Nord, M., Smith, T. A., Williams, R., Kinnison, K., Olander, C., Singh, A., \& Tuckermanty, E. (2009). Access to affordable and nutritious food-Measuring and understanding food deserts and their consequences: Report to Congress (USDA Economic Research Service Administrative Publication No. AP-036). Retrieved from http://www.ers.usda.gov/publications/apadministrative-publication/ap-036.aspx

Vermont Center for Geographic Information [VCGI]. (n.d.). E911 Site Locations [GIS data layer]. Retrieved from http://maps.vcgi.org/gisdata/vcgi/ packaged zips/EmergencyE911 ESITE.zip

Walker, R. E., Keane, C. R., \& Burke, J. G. (2010). Disparities and access to healthy food in the United States: A review of food deserts literature. Health \& Place, 16(5), 876-884. http://dx.doi.org/10.1016/ j.healthplace.2010.04.013

Whelan, A., Wrigley, N., Warm, D., \& Cannings, E. (2002). Life in a "food desert." Urban Studies, 39(11), 2083-2100. http://dx.doi.org/10.1080/0042098022000011371

Wrigley, N., Warm, D., \& Margetts, B. (2003). Deprivation, diet, and food-retail access: Findings from the Leeds "food deserts" study. Environment and Planning A, 35(1), 151-188. http://dx.doi.org/10.1068/a35150 
Wrigley, N., Warm, D., Margetts, B., \& Whelan, A. (2002). Assessing the impact of improved retail access on diet in a "food desert": A preliminary report. Urban Studies, 39(11), 2061-2082. http://dx.doi.org/10.1080/0042098022000011362

Worthington, V. (2001). Nutritional quality of organic versus conventional fruits, vegetables, and grains. The Journal of Alternative and Complementary Medicine, 7(2), 161-173.

http://dx.doi.org/10.1089/107555301750164244
Zenk, S. N., Schultz, A. J., Israel, B. A., James, S. A., Bao, S., \& Wilson, M. L. (2006). Fruit and vegetable access differs by community racial composition and socioeconomic position in Detroit, Michigan. Ethnicity and Disease, 16(1), 275-280. 